\title{
Associations Between Gene Polymorphisms of Vascular Endothelial Growth Factor and Prostate Cancer
}

\author{
HENRIETA DROBKOVÁ ${ }^{1}$, JANA JUREČEKOVÁ ${ }^{2}$, MONIKA KMEŤOVÁ SIVOŇOVÁ ${ }^{2}$, JANA MAZUCHOVÁ ${ }^{3}$, \\ MICHAELA ŠKORVANOVÁ ${ }^{2}$, MIROSLAVA ŠARLINOVÁ ${ }^{1}$, ERIKA HALAŠOVÁ ${ }^{1,3}$ and JÁN KLIMENT ${ }^{4}$ \\ ${ }^{1}$ Department of Molecular Medicine, Jessenius Faculty of Medicine in Martin, \\ Biomedical Center Martin, Comenius University in Bratislava, Martin, Slovak Republic; \\ ${ }^{2}$ Department of Medical Biochemistry, Jessenius Faculty of Medicine in Martin, \\ Comenius University in Bratislava, Martin, Slovak Republic; \\ ${ }^{3}$ Department of Medical Biology, Jessenius Faculty of Medicine in Martin, \\ Comenius University in Bratislava, Martin, Slovak Republic; \\ ${ }^{4}$ Department of Urology, Jessenius Faculty of Medicine in Martin and University Hospital Martin, \\ Comenius University in Bratislava, Martin, Slovak Republic
}

\begin{abstract}
Background/Aim: The aim of this study was to evaluate the association between selected polymorphisms of the vascular endothelial growth factor gene (rs699947, rs 144854329, rs833061, rs2010963, rs3025039) and the risk of prostate cancer development and progression. Materials and Methods: The present study included 446 patients with prostate cancer and 241 healthy men. Genotyping was performed by polymerase-chain reaction-restriction fragment length polymorphism analysis. Results: No significant association between the individual polymorphisms studied and the risk of prostate cancer development was detected. A statistically significantly increased risk of prostate cancer development associated with the presence of 9 or 10 risky alleles was found considering the whole group of patients, as well as in patients with low-grade carcinomas (Gleason score $<7)$. Conclusion: Individual polymorphisms of VEGF do not appear to contribute to prostate cancer. However, a combination of risky alleles of the studied polymorphisms significantly increases the risk of prostate cancer in Slovak patients.
\end{abstract}

Prostate cancer is highly heterogeneous disease and the exact cause of its origin is not yet known. Different molecular pathways, including angiogenesis, play an important role in

Correspondence to: Jurečeková Jana, Dept. of Medical Biochemistry, Jessenius Faculty of Medicine in Martin, Comenius University in Bratislava, Malá Hora 4, 03601 Martin, Slovak Republic. Tel: +42 1432633668, e-mail: jurecekova@jfmed.uniba.sk

Key Words: Vascular endothelial growth factor, prostate cancer, polymorphism. pathogenesis of prostate cancer and involve a large number of specific proteins, including growth factors and cytokines.

Vascular endothelial growth factor (VEGF) is homodimeric, heparin-bound glycoprotein which belongs to a group of proangiogenic factors (1). It is a key factor that stimulates physiological, as well as tumour angiogenesis $(2,3)$. VEGF is a specific mitogen of endothelial cells that increases vascular permeability and activates the VEGF signalling pathway (4). This pathway induces proliferation, migration and invasion of endothelial cells that are able to reduce and to remodel the extracellular matrix. These processes result in the initiation of angiogenesis $(2,5-7)$. VEGF promotes dedifferentiation of tumour cells and their better survival through autocrine VEGF signalling. This growth factor facilitates tumour cell entry into the circulation by increasing vascular permeability and it allows metastasis to distant sites $(1,2,8,9)$.

The gene encoding VEGF is located on chromosome 6 (6p21.1) and comprises a 14-kilobase coding region with eight exons and seven introns (10). Polymorphisms of the VEGF gene may contribute to the malignant transformation of prostate cells or can affect disease progression, metastasis and the effectiveness of therapy by change in transcription of the gene and subsequently increased production of intracellular VEGF protein (11-14).

The main objective of this study was to determine the role of VEGF gene polymorphisms (-2578 rs699947; 18 bp I/D rs144854329; -460 rs833061; -634 rs2010963 and +936 rs3025039) in the development and progression of prostate cancer.

\section{Materials and Methods}

Study population. The present case-control study included 446 patients with histologically verified prostate cancer [mean 
age $=66.8 \pm 8.09$ years; median prostate specific antigen $(\mathrm{PSA})=9.18$ $\mathrm{ng} / \mathrm{ml}$ (interquartile range $=5.30-20.07 \mathrm{ng} / \mathrm{ml}$ ); mean Gleason score $7.03 \pm 1.30$ ] and 241 controls [mean age $=57.99 \pm 9.73$ years; median $\mathrm{PSA}=1.06 \mathrm{ng} / \mathrm{ml}$ (interquartile range $=0.54-2.39 \mathrm{ng} / \mathrm{ml}$ )]. Healthy men for the control group were selected during routine urological examination and were confirmed to be without any prostatic disease and individual cancer history.

Genotyping. Venous blood ( $5 \mathrm{ml}$ ) was taken into K2EDTA tubes from all of the men. Isolation of genomic DNA from whole blood samples was carried out using Wizard ${ }^{\circledR}$ Genomic DNA Purification kit (Promega, Madison, WI, USA). Genomic DNA samples were stored at $-20^{\circ} \mathrm{C}$ until genotypic analysis. The $V E G F$ gene polymorphisms were determined by polymerase-chain reaction (PCR)-restriction fragment length polymorphism analysis. Amplification of the DNA fragments was performed in a $12-\mu 1$ master mix consisting of: $1 \mu \mathrm{l}$ of genomic DNA, $6 \mu \mathrm{l}$ Dream Taq Green PCR Master mix (2x), 0.4-0.5 $\mu$ l of each primer (25 $\mu \mathrm{mol} / \mu \mathrm{l})$ and 4-4.2 $\mu \mathrm{l}$ of DNase-free water. The primer sequences used for detection of the $V E G F$ gene polymorphisms are listed in Table I. The PCR amplification conditions were as follows: 5 min of initial denaturation at $95^{\circ} \mathrm{C}$, and $28-35$ cycles (depending on the primers used) consisting of 30-50 s of denaturation at $95^{\circ} \mathrm{C}, 30-40 \mathrm{~s}$ hybridization at different annealing temperatures (Table I) and $45-50 \mathrm{~s}$ elongation at $72^{\circ} \mathrm{C}$, followed by a $5-10 \mathrm{~min}$ final elongation at $72^{\circ} \mathrm{C}$. PCR products were subsequently digested with specific restriction enzymes for 15-30 min at $37^{\circ} \mathrm{C}$ (Table I). Only the $18 \mathrm{bp} \mathrm{I/D} \mathrm{VEGF} \mathrm{polymorphism}$ was determined by sequence-specific primers. Digested products were separated using electrophoresis on $2 \%$ or $4 \%$ agarose gels and visualized by ethidium bromide staining.

Statistical analysis. Chi-square test and Fisher's exact test were used to compare the genotypic distribution between patients with prostate cancer and healthy men and to evaluate association with selected clinical data as well as combinations of polymorphisms. Genotypic frequencies of individual polymorphisms were tested for HardyWeinberg equilibrium in the control group. Associations were considered to be statistically significant when $p \leq 0.05$. StatsDirect statistical package version 2.7.0.2 (StatsDirect Ltd, Cambridge, UK) was used for statistical analysis.

\section{Results}

Main clinical characteristics of patients (446) and controls (241) are reported in Table II. Five polymorphisms of the $V E G F$ gene were evaluated: rs699947 at -2578 , rs144854329 at -2549 , and rs833061 at -460 , all located in the promoter region; rs2010963 at -634 in the 5'-untranslated region of the gene; and rs3025039 at +936 in the 3'-untranslated region of the gene. The distribution of genotypes of observed polymorphisms in the patients and control group is summarized in Table III. Distribution of genotypes in the control group was in Hardy-Weinberg equilibrium for all polymorphisms of $V E G F$ gene ( $>>0.05)$, except the -634 $V E G F$ polymorphism $(p=0.007)$.

No significant association between individual polymorphisms and risk of prostate cancer development and progression in the group of patients overall was found (Table III). Subsequently, the patients were stratified according to Gleason score (Gleason score $<7$ and Gleason score $\geq 7$, eventually Gleason score $\geq 8$ ) and prostate specific antigen (PSA $<10 \mathrm{ng} / \mathrm{ml}$ and PSA $\geq 10 \mathrm{ng} / \mathrm{ml}$ ) in order to detect any possible correlation between $V E G F$ gene polymorphisms and aggressiveness of prostate cancer. Although no significant association between individual polymorphisms and aggressiveness of prostate cancer was found, the GC genotype of the $-634 V E G F$ polymorphism was borderline associated with increased risk of prostate cancer development in patients with Gleason score $<7(\mathrm{OR}=1.58,95 \% \mathrm{CI}=0.97$ 2.57, $p=0.06$ ) (Table IV). The frequency of the both the $\mathrm{CC}$ genotype $(\mathrm{OR}=1.76,95 \% \mathrm{CI}=0.91-3.40, p=0.089)$ and the $\mathrm{C}$ allele $(\mathrm{OR}=1.38,95 \% \mathrm{CI}=0.96-1.99, p=0.08)$ of the -634 $V E G F$ polymorphism was higher in patients with prostate cancer with Gleason score $\geq 8$ (Table IV). The frequency of the $\mathrm{CC}$ genotype was also higher in patients with $\mathrm{PSA} \geq 10$ $\mathrm{ng} / \mathrm{ml}$ compared to the control group ( $\mathrm{OR}=1.63,95 \%$ $\mathrm{CI}=0.95-2.80, p=0.078$ ) (Table V). However, the results were on the border of statistical significance. The $\mathrm{CC}$ genotype was significantly associated with increased risk of prostate cancer development in patients with PSA $\geq 10 \mathrm{ng} / \mathrm{ml}$ compared to those with PSA $<10 \mathrm{ng} / \mathrm{ml}(\mathrm{OR}=1.92,95 \% \mathrm{CI}=1.04-3.55$, $p=0.036$ ) (Table V).

Combination of five polymorphisms of $V E G F$ gene was evaluated according to number of variant (risky) alleles. The following alleles were considered risky: $-2578 \mathrm{C}, 18 \mathrm{bp} \mathrm{D}$, $-460 \mathrm{~T},-634 \mathrm{C}$ and $+936 \mathrm{~T}$. The presence of 9 or 10 risky alleles was associated with statistically significant increased risk of prostate cancer development considering the whole group of patients $(\mathrm{OR}=2.34,95 \% \mathrm{CI}=1.1-4.98, p=0.03)$ (Table VI) as well as in patients with low-grade carcinomas (Gleason score $<7)(\mathrm{OR}=4.18,95 \% \mathrm{CI}=1.25-13.98, p=0.015)$ (Table VII).

\section{Discussion}

The $V E G F$ gene is highly polymorphic and its expression may be affected by several polymorphisms. The exact mechanism of influence of these polymorphisms has not been elucidated yet but it is supposed that they might affect the transcriptional activity of the $V E G F$ gene and consequently alter concentrations of VEGF. Since VEGF promotes angiogenesis, it is possible that higher concentrations of VEGF in the tumour microenvironment induce more rapid progression and survival of residual tumour cells and may contribute to the development of metastases or local recurrence of disease (11). In our study, we investigated polymorphisms that have not been studied in relation to prostate cancer or for which published results are contradictory.

The -2578 VEGF polymorphism lies within the potential GATA binding protein 2 (GATA-2) binding site and the $\mathrm{C}$ 
Table I. Specific conditions for analysis of individual polymorphisms of the vascular endothelial growth factor (VEGF) gene.

\begin{tabular}{|c|c|c|c|c|}
\hline Position in $V E G F$ gene & $\begin{array}{l}\text { Sequence of forward }(F) \text { and } \\
\text { reverse }(R) \text { primers }\left(5^{\prime}-3^{\prime}\right)\end{array}$ & $\begin{array}{l}\text { Annealing } \\
\text { temperature }\end{array}$ & $\begin{array}{l}\text { Restriction } \\
\text { enzyme }\end{array}$ & $\begin{array}{l}\text { Product } \\
\text { (bp) }\end{array}$ \\
\hline \multirow[t]{2}{*}{$-2578 \mathrm{~A} / \mathrm{C}$} & F: GCA CCT CCA CCA AAC CAC AGC AAC AT & \multirow[t]{2}{*}{$62^{\circ} \mathrm{C}$} & \multirow[t]{2}{*}{$B g \mathrm{III}$} & \multirow[t]{2}{*}{$360 ; 205,155$} \\
\hline & R: CAA GCC CCC TTT TCC TCC AAC TCT CC & & & \\
\hline \multirow[t]{2}{*}{$18 \mathrm{bp} \mathrm{I/D}$} & F: CCT GGA GCG TTT TGG TTA AA & \multirow[t]{2}{*}{$59^{\circ} \mathrm{C}$} & \multirow[t]{2}{*}{-} & \multirow[t]{2}{*}{234,216} \\
\hline & R: ATA TAG GAA GCA GCT TGG AA & & & \\
\hline \multirow[t]{2}{*}{$-460 \mathrm{C} / \mathrm{T}$} & F: CTC TTT AGC CAG AGC CGG GG & \multirow[t]{2}{*}{$60^{\circ} \mathrm{C}$} & \multirow[t]{2}{*}{$\operatorname{Hin} 1 \mathrm{I}$} & \multirow[t]{2}{*}{$175 ; 153,22$} \\
\hline & R: TGG CCT TCT CCC CGC TCC GAC & & & \\
\hline \multirow[t]{2}{*}{$-634 \mathrm{G} / \mathrm{C}$} & F: ATT TAT TTT TGC TTG CCA TT & \multirow[t]{2}{*}{$55.7^{\circ} \mathrm{C}$} & \multirow[t]{2}{*}{ Faq $\mathrm{I}$} & \multirow[t]{2}{*}{$204 ; 193,111$} \\
\hline & R: GTC TGT CTG TCT GTC CGT CA & & & \\
\hline \multirow[t]{2}{*}{$+936 \mathrm{C} / \mathrm{T}$} & F: AAG GAA GAG GAG ACT CTG CGC AGA GC & \multirow[t]{2}{*}{$63^{\circ} \mathrm{C}$} & \multirow[t]{2}{*}{ NIaIII } & \multirow[t]{2}{*}{$208 ; 122,86$} \\
\hline & R: TAA ATG TAT GTA TGT GGG TGG GTG TGT CTA CAG & & & \\
\hline
\end{tabular}

allele might stimulate the activation of the promoter of $V E G F$ gene through the GATA-2 transcriptional factor (12, 15). We did not find a statistically significant association between this polymorphism and risk of prostate cancer development, nor with clinical characteristics (pathological Gleason score, PSA). Some other studies similarly did not observe any association between the risk of prostate cancer development and progression (pathological stage, pathological grade, PSA concentrations at diagnosis, or age) $(16,17)$ or clinical recurrence of disease $(18)$. In contrast with previous studies, Martinez-Fierro et al. found a 6.1-fold increased risk of prostate cancer development to be associated with the CC genotype of the -2578 VEGF in the Mexican population. However, these authors did not observe statistically significant association of this polymorphism with progression of prostate cancer (Gleason score, PSA) (12).

The second polymorphism localized in the promoter region studied was the polymorphism $18 \mathrm{bp} \mathrm{I/D} \mathrm{VEGF.} \mathrm{To}$ our knowledge, this appears to be the first study evaluating possible association of this polymorphism with prostate cancer. The functional mechanism of this polymorphism is not known yet, but it is supposed that the presence of the D allele may be associated with increased transcription, which would probably lead to increased VEGF concentration (19). We did not find any association between the $18 \mathrm{bp} \mathrm{I/D}$ $V E G F$ polymorphism and prostate cancer or some clinical characteristics of the disease (Gleason score, PSA). Similar results were reported by Ungerbäck et al. in a study evaluating this polymorphism in connection with colorectal cancer (20). On the contrary, a higher frequency of the II genotype and I allele of $18 \mathrm{bp} \mathrm{I/D} \mathrm{VEGF} \mathrm{was} \mathrm{found} \mathrm{in}$ patients with breast cancer in comparison to healthy individuals (21). This polymorphism was reported to be in complete linkage with single nucleotide polymorphism -2578 VEGF and individuals with the $-2578 \mathrm{~A}$ allele have an insertion of 18 bp $(19,22)$. We observed similar results in our study.
Table II. Characteristics of control group and patients with prostate cancer.

\begin{tabular}{lcc}
\hline Characteristic & $\begin{array}{c}\text { Control group } \\
(\mathrm{N}=241)\end{array}$ & $\begin{array}{c}\text { Prostate cancer } \\
(\mathrm{N}=446)\end{array}$ \\
\hline $\begin{array}{c}\text { Age (years) } \\
\text { Mean } \pm \text { SD }\end{array}$ & $57.99 \pm 9.73$ & $66.8 \pm 8.09$ \\
$\begin{array}{l}\text { PSA (ng/ml) } \\
\text { Median }(25 \text { th-75th percentile) }\end{array}$ & $1.06(0.54-2.39)$ & $9.18(5.30-20.07)$ \\
$\begin{array}{l}\text { Gleason score } \\
\text { Mean } \pm \text { SD }\end{array}$ & $\mathrm{NA}$ & $7.03 \pm 1.30$ \\
\hline
\end{tabular}

NA: Not applicable; PSA: prostate-specific antigen; SD: standard deviation.

The final polymorphism in the promoter region of $V E G F$ studied here is localized at the -460 position. Although it is supposed that the presence of the $\mathrm{C}$ allele may affect VEGF concentration (11), the exact functional mechanism of this polymorphism is not known yet. In our study, we found no association between the -460 VEGF polymorphism and the risk of prostate cancer development and progression. Other studies reported similar results $(11,16)$. On the contrary, Onen et al. reported that the CT genotype of $-460 \mathrm{VEGF}$ polymorphism was associated with an increased risk of developing pT3a-T4b tumours in a Turkish population $(\mathrm{OR}=2.42,95 \% \mathrm{CI}=1.09-5.39, p=0.027)$ (23). Another study in a Taiwanese population reported that the $\mathrm{T}$ allele of this polymorphism was associated with increased risk of prostate cancer and the TT genotype was considered as the risky genotype (24). Different results were reported by Fukuda et al. (11). They found that $C$ allele-bearing genotypes of -460 $V E G F$ were significantly associated with a higher likelihood of clinical recurrence of disease (increase of PSA) in patients after radical prostatectomy. On the other hand, the TT genotype of this polymorphism was associated with statistically significantly worse survival in those with metastatic disease (11). 
Table III. Distribution of the genotypes of vascular endothelial growth factor (VEGF) polymorphisms.

\begin{tabular}{|c|c|c|c|c|c|}
\hline$V E G F$ polymorphism & Genotype & Control group (\%) & Prostate cancer $(\%)$ & OR $(95 \% \mathrm{CI})$ & $p$-Value \\
\hline \multirow[t]{3}{*}{$-2578 \mathrm{~A} / \mathrm{C}$} & $\mathrm{AA}$ & 25.73 & 28.70 & 1.00 (ref.) & \\
\hline & $\mathrm{AC}$ & 48.54 & 45.07 & $0.91(0.62-1.34)$ & 0.63 \\
\hline & $\mathrm{CC}$ & 25.73 & 26.23 & $1.09(0.71-1.69)$ & 0.68 \\
\hline \multirow[t]{3}{*}{$18 \mathrm{bp} \mathrm{I/D}$} & II & 26.55 & 26.01 & 1.00 (ref.) & \\
\hline & ID & 47.72 & 45.74 & $0.98(0.67-1.43)$ & 0.91 \\
\hline & DD & 25.73 & 28.25 & $1.12(0.73-1.73)$ & 0.60 \\
\hline \multirow[t]{3}{*}{$-460 \mathrm{C} / \mathrm{T}$} & $\mathrm{CC}$ & 25.73 & 26.23 & 1.00 (ref.) & \\
\hline & $\mathrm{CT}$ & 48.54 & 45.07 & $0.91(0.62-1.34)$ & 0.63 \\
\hline & TT & 25.73 & 28.70 & $1.09(0.71-1.69)$ & 0.68 \\
\hline \multirow[t]{3}{*}{$-634 \mathrm{G} / \mathrm{C}$} & GG & 46.22 & 44.42 & 1.00 (ref.) & \\
\hline & $\mathrm{GC}$ & 36.55 & 37.38 & $1.06(0.75-1.52)$ & 0.73 \\
\hline & $\mathrm{CC}$ & 17.23 & 18.20 & $1.10(0.7-1.72)$ & 0.68 \\
\hline \multirow[t]{3}{*}{ +936 C/T } & $\mathrm{CC}$ & 71.37 & 73.48 & 1.00 (ref.) & \\
\hline & CT & 24.48 & 23.37 & $0.93(0.64-1.34)$ & 0.69 \\
\hline & TT & 4.15 & 3.15 & $0.74(0.32-1.69)$ & 0.47 \\
\hline
\end{tabular}

CI: Confidence intervaI; OR: odds ratio.

Table IV. Association between the genotypes of the -634 G/C vascular endothelial growth factor (VEGF) polymorphism and prostate cancer risk in patients stratified according to Gleason score.

\begin{tabular}{|c|c|c|c|c|c|c|c|c|c|}
\hline \multirow{2}{*}{$\begin{array}{l}-634 \mathrm{G} / \mathrm{C} \\
V E G F\end{array}$} & \multicolumn{2}{|c|}{ Gleason score $<7(\mathrm{~N}=121)$} & \multicolumn{4}{|c|}{ Gleason score $\geq 7(\mathrm{~N}=184)$} & \multicolumn{2}{|c|}{ Gleason score $\geq 8(\mathrm{~N}=81)$} & \multirow[b]{2}{*}{$p$-Value } \\
\hline & Frequency $(\%)$ & OR $(95 \% \mathrm{CI})$ & $p$-Value & Frequency $(\%)$ & OR $(95 \% \mathrm{CI})$ & $p$-Value & Frequency $(\%)$ & OR $(95 \% \mathrm{CI})$ & \\
\hline GG & 36.4 & 1.00 (ref.) & & 41.85 & 1.00 (ref.) & & 39.5 & 1.00 (ref.) & \\
\hline GC & 45.4 & $1.58(0.97-2.57)$ & 0.06 & 36.96 & $1.12(0.73-1.72)$ & 0.62 & 34.57 & $1.11(0.62-1.98)$ & 0.73 \\
\hline $\mathrm{CC}$ & 18.2 & $1.34(0.72-2.51)$ & 0.36 & 21.19 & $1.36(0.80-2.30)$ & 0.25 & 25.93 & $1.76(0.91-3.40)$ & 0.089 \\
\hline Allele G & 59.1 & 1.00 (ref.) & & 60.33 & 1.00 (ref.) & & 56.79 & 1.00 (ref.) & \\
\hline Allele C & 40.9 & $1.26(0.92-1.73)$ & 0.16 & 39.67 & $1.20(0.90-1.58)$ & 0.21 & 43.21 & $1.38(0.96-1.99)$ & 0.08 \\
\hline
\end{tabular}

CI: Confidence intervaI; OR: odds ratio.

Table V. Association between the genotypes of the -634 G/C vascular endothelial growth factor (VEGF) polymorphism and prostate cancer risk in patients stratified according to prostate-specific antigen (PSA).

\begin{tabular}{|c|c|c|c|c|c|c|c|c|}
\hline \multirow{2}{*}{$\begin{array}{l}-634 \mathrm{G} / \mathrm{C} \\
V E G F\end{array}$} & \multicolumn{3}{|c|}{ PSA $<10 \mathrm{ng} / \mathrm{ml}(\mathrm{N}=178)$} & \multicolumn{3}{|c|}{$\mathrm{PSA} \geq 10 \mathrm{ng} / \mathrm{ml}(\mathrm{N}=150)$} & \multicolumn{2}{|c|}{ PSA $<10 v s . \geq 10 \mathrm{ng} / \mathrm{m}$} \\
\hline & Frequency $(\%)$ & OR $(95 \% \mathrm{CI})$ & $p$-Value & Frequency $(\%)$ & OR $(95 \% \mathrm{CI})$ & $p$-Value & OR $(95 \% \mathrm{CI})$ & $p$-Value \\
\hline GG & 42.7 & 1.00 (ref.) & & 40.67 & 1.00 (ref.) & & 1.00 (ref.) & \\
\hline GC & 43.82 & $1.298(0.85-1.98)$ & 0.23 & 34.67 & $1.08(0.68-1.72)$ & 0.75 & $0.83(0.51-1.35)$ & 0.45 \\
\hline $\mathrm{CC}$ & 13.48 & $0.84(0.47-1.52)$ & 0.58 & 24.66 & $1.63(0.95-2.80)$ & 0.078 & $1.92(1.04-3.55)$ & 0.036 \\
\hline Allele G & 64.61 & 1.00 (ref.) & & 58 & 1.00 (ref.) & & 1.00 (ref.) & \\
\hline Allele C & 35.39 & $0.995(0.75-1.33)$ & 0.97 & 42 & $1.32(0.98-1.77)$ & 0.069 & $1.32(0.96-1.81)$ & 0.08 \\
\hline
\end{tabular}

CI: Confidence intervaI; OR: odds ratio. Statistically significant results are highlighted in bold.

The next polymorphism we studied is localized at position -634 in the 5' untranslated region of VEGF gene. The functional mechanism by which this polymorphism affects prostate cancer cells has not been explained in any study yet.
Orlandi et al. assumed that this polymorphism may increase the concentration of intracellular VEGF protein and thus change the response of patients to treatment (13). In our study, we found no statistically significant association 
Table VI. Analysis of combination of five vascular endothelial growth factor (VEGF) polymorphisms and their association with prostate cancer.

\begin{tabular}{|c|c|c|c|c|}
\hline Number of risky alleles* & Control group (\%) & Prostate cancer $(\%)$ & OR $(95 \% \mathrm{CI})$ & $p$-Value \\
\hline $0+1$ & 8.29 & 5.35 & 1.00 (ref.) & \\
\hline $2+3+4$ & 25.81 & 25.55 & $1.53(0.76-3.1)$ & 0.23 \\
\hline $5+6$ & 44.24 & 37.71 & $1.32(0.67-2.59)$ & 0.42 \\
\hline $7+8$ & 8.76 & 11.92 & $2.11(0.93-4.78)$ & 0.07 \\
\hline $9+10$ & 12.9 & 19.47 & $2.34(1.1-4.98)$ & 0.03 \\
\hline
\end{tabular}

CI: Confidence intervaI; OR: odds ratio. Statistically significant results are highlighted in bold. *Variant alleles considered as risky: $-2578 \mathrm{C}, 18$ bp D, $-460 \mathrm{~T},-634 \mathrm{C}$ and $+936 \mathrm{~T}$.

Table VII. Analysis of combination of five vascular endothelial growth factor (VEGF) polymorphisms and their association with prostate cancer in patients stratified according to Gleason score.

\begin{tabular}{|c|c|c|c|c|c|c|}
\hline \multirow[t]{2}{*}{ Number of risky alleles* } & \multicolumn{3}{|c|}{ Gleason score $<7(\mathrm{~N}=121)$} & \multicolumn{3}{|c|}{ Gleason score $\geq 7(\mathrm{~N}=184)$} \\
\hline & Patients (\%) & OR $(95 \% \mathrm{CI})$ & $p$-Value & Patients (\%) & OR $(95 \% \mathrm{CI})$ & $p$-Value \\
\hline $0+1$ & 3.28 & 1.00 (ref.) & & 7.95 & 1.00 (ref.) & \\
\hline $2+3+4$ & 24.59 & $2.41(0.75-7.77)$ & 0.13 & 27.81 & $1.13(0.49-2.59)$ & 0.78 \\
\hline $5+6$ & 40.16 & $2.29(0.74-7.16)$ & 0.14 & 41.72 & $0.98(0.44-2.18)$ & $>0.99$ \\
\hline $7+8$ & 10.66 & $3.08(0.85-11.22)$ & 0.08 & 15.90 & $1.89(0.74-4.88)$ & 0.18 \\
\hline $9+10$ & 21.31 & $4.18(1.25-13.98)$ & 0.015 & 6.62 & $0.54(0.19-1.5)$ & 0.23 \\
\hline
\end{tabular}

CI: Confidence intervaI; OR: odds ratio. Statistically significant results are highlighted in bold. *Variant alleles considered as risky: $-2578 \mathrm{C}, 18$ bp D, $-460 \mathrm{~T},-634 \mathrm{C}$ and $+936 \mathrm{~T}$.

between the $-634 V E G F$ polymorphism and risk of prostate cancer development in patients overall. Langsenlehner et al. similarly reported no association between this polymorphism and aggressiveness of prostate cancer (Gleason score, pathological stage and PSA) (16) or clinical recurrence of disease (18). Unlike these results, Sfar et al. reported that the combination of the CG with CC genotypes of -634 VEGF was associated with an increased risk of prostate cancer development $(\mathrm{OR}=1.95, p=0.02)$ in a Tunisian population. They also observed a highly significant association of the GC $(\mathrm{OR}=3.83, p=0.001)$ and $\mathrm{CC}(\mathrm{OR}=4.89, p=0.004)$ genotypes of this polymorphism with an increased risk of high-grade disease (14). Similarly to these results, we found that the frequency of the CC genotype of $-634 V E G F$ was higher in patients with prostate cancer with Gleason score $\geq 8$ and in patients with $P S A \geq 10 \mathrm{ng} / \mathrm{ml}$ compared to the control group. On the contrary to previous study, we observed that the GC genotype of $-634 V E G F$ was associated with increased risk of prostate cancer development in patients with Gleason score $<7$. The results of previous studies point to the possible role of this polymorphism in the development and progression of prostate cancer.

The TT genotype of the polymorphism localized at the +936 position in the 3' untranslated region of $V E G F$ was reportedly associated with lower serum concentrations of
VEGF compared to the CC genotype in a healthy population (25). Therefore, it is assumed that the $+936 \mathrm{C} / \mathrm{T} V E G F$ polymorphism might alter VEGF concentrations and thus alter the response of patients to treatment (13). We found no association between this polymorphism and the risk of prostate cancer development or its aggressiveness (Gleason score and PSA) similarly to other studies $(14,16)$. Langsenlehner et al. also found no association of this polymorphism with clinical recurrence of disease (18).

Although the individual VEGF gene polymorphisms had no effect on the risk of prostate cancer development and progression, the analysis of combinations of the studied polymorphisms showed significant differences between patients with prostate cancer and a group of healthy individuals. The presence of 9 or 10 risky alleles of these polymorphisms $(-2578 \mathrm{C}, 18$ bp D, -460T, $-634 \mathrm{C}$ and +936T) significantly increased the risk of prostate cancer. To our knowledge, this is the first study on correlation of combinations of $V E G F$ polymorphisms with prostate cancer development and prognosis.

In conclusion, our study may help clarify the role of $V E G F$ polymorphisms in the etiopathogenesis of prostate cancer. Prostate cancer is a multifactorial disease and its development and progression may be promoted not only by VEGF but also by various other factors. The identification 
of specific gene polymorphisms, or combinations of these polymorphisms in selected genes, might contribute to earlier diagnosis of the disease, as well as helping distinguish lowrisk from high-risk prostate cancer and thereby determine the aggressiveness of prostate cancer.

\section{Conflicts of Interest}

The Authors confirm that there are no conflicts of interest in regard to this study.

\section{Authors' Contributions}

Study concept and design: HD, JJ, MKS, EH and JK. Performed the experiments: HD, JJ, JM, MŠk and MŠa. Acquisition of data: HD, JJ and JK. Statistical analysis and interpretation of data: HD, JJ, MKS and JK. Drafting and writing of the article: HD and JJ. Technical or material support: MKS and EH. All Authors read and approved the final article.

\section{Acknowledgements}

This work was supported by the Agency of Ministry of Education, Science, Research and Sport of the Slovak Republic under grants VEGA no. 1/0172/18 and 1/0271/19, by the grant APVV-15-0181. This work was also supported by the project "Competence Center for Research and Development in the Field of Diagnostics and Therapy of Oncological Diseases (ITMS code: 26220220153).

\section{References}

1 Amankwah EK, Sellers TA and Park JY: Gene variants in the angiogenesis pathway and prostate cancer. Carcinogenesis 33: 1259-1269, 2012. PMID: 22523086. DOI: 10.1093/carcin/ bgs 150

2 Goel HL and Mercurio AM: VEGF targets the tumour cell. Nat Rev Cancer 13: 871-882, 2013. PMID: 24263190. DOI: $10.1038 / \mathrm{nrc} 3627$

3 Leung DW, Cachianes G, Kuang WJ, Goeddel DV and Ferrara $\mathrm{N}$ : Vascular endothelial growth factor is a secreted angiogenic mitogen. Science 246: 1306-1309, 1989. PMID: 2479986. DOI: $10.1126 /$ science 2479986

4 Tischer E, Mitchell R, Hartman T, Silva M, Gospodarowicz D, Fiddes JC and Abraham JA: The human gene for vascular endothelial growth factor. Multiple protein forms are encoded through alternative exon splicing. J Biol Chem 266: 1194711954, 1991. PMID: 1711045.

5 Gleave ME, Cox ME and Wang Y: Cell biology of prostate cancer and molecular targets. In: Drug Management of Prostate Cancer. Figg W, Chau CH and Small EJ (eds.). New York, SpringerVerlag, pp. 1-24, 2010. DOI: 10.1007/978-1-60327-829-4

6 Kowanetz M and Ferrara N: Vascular endothelial growth factor signaling pathways: therapeutic perspective. Clin Cancer Res 12: 5018-5022, 2006. PMID: 16951216. DOI: 10.1158/10780432.CCR-06-1520

7 Sissung TM, Price DK, Del Re M, Ley AM, Giovannetti E, Figg WD and Danesi R: Genetic variation: Effect on prostate cancer. Biochem Biophys Acta 1846: 446-456, 2014. PMID: 25199985. DOI: $10.1016 /$ j.bbcan.2014.08.007
8 Russo G, Mischi M, Scheepens W, De la Rosette JJ and Wijkstra $\mathrm{H}$ : Angiogenesis in prostate cancer: Onset, progression and imaging. BJU Int 110: E794-808, 2012. PMID: 22958524. DOI: 10.1111/j.1464-410X.2012.11444.x

9 Veikkola T, Karkkainen M, Claesson-Welsh L and Alitalo K: Regulation of angiogenesis via vascular endothelial growth factor receptors. Cancer Res 60: 203-212, 2000. PMID: 10667560.

10 Brogan IJ, Khan N, Isaac K, Hutchinson JA, Pravica V and Hutchinson IV: Novel polymorphisms in the promoter and 5' UTR regions of the human vascular endothelial growth factor gene. Hum Immunol 60: 1245-1249, 1999. PMID: 10626738. DOI: $10.1016 /$ S0198-8859(99)00132-9

11 Fukuda H, Tsuchiya N, Narita S, Kumazawa T, Horikawa Y, Inoue T, Saito M, Yuasa T, Matsuura S, Satoh S, Ogawa O and Habuchi T: Clinical implication of vascular endothelial growth factor T-460C polymorphism in the risk and progression of prostate cancer. Oncol Rep 18: 1155-1163, 2007. PMID: 17914 566. DOI: $10.3892 /$ or.18.5.1155

12 Martinez-Fierro ML, Garza-Veloz I, Rojas-Martinez A, OrtizLopez R, Castruita-de la Rosa C, Ortiz-Castro Y, LazaldeRamos BP, Cervantes-Villagrana AR, Castañeda-Lopez ME, Gomez-Guerra L, Delgado-Enciso I and Martinez-Torres AA: Positive association between vascular endothelial growth factor $(V E G F)-2578 \mathrm{C} / \mathrm{A}$ variant and prostate cancer. Cancer Biomark 13: 235-241, 2013. PMID: 24240584. DOI: 10.3233/CBM-130348

13 Orlandi P, Fontana A, Fioravanti A, Di Desidero T, Galli L, Derosa L, Canu B, Marconcini R, Biasco E, Solini A, Francia G, Danesi R, Falcone A and Bocci G: VEGF-A polymorphisms predict progression-free survival among advanced castrationresistant prostate cancer patients treated with metronomic cyclophosphamide. Br J Cancer 109: 957-964, 2013. PMID: 23860526. DOI: $10.1038 /$ bjc.2013.398

14 Sfar S, Hassen E, Saad H, Mosbah F and Chouchane L: Association of $V E G F$ genetic polymorphisms with prostate carcinoma risk and clinical outcome. Cytokine 35: 21-28, 2006. PMID: 16908180. DOI: 10.1016/j.cyto.2006.07.003

15 Nasr HB, Chahed K, Bouaouina N and Chouchane L: Functional vascular endothelial growth factor $-2578 \mathrm{C} / \mathrm{A}$ polymorphism in relation to nasopharyngeal carcinoma risk and tumor progression. Clin Chim Acta 395: 124-129, 2008. PMID: 18588866. DOI: 10.1016/j.cca.2008.05.022

16 Langsenlehner T, Langsenlehner U, Renner W, Krippl P, Mayer R, Wascher TC and Kapp KS: Single nucleotide polymorphisms and haplotypes in the gene for vascular endothelial growth factor and risk of prostate cancer. Eur J Cancer 44: 1572-1576, 2008. PMID: 18514506. DOI: 10.1016/j.ejca.2008.04.021

17 VanCleave TT, Moore JH, Benford ML, Brock GN, Kalbfleisch T, Baumgartner RN, Lillard JW Jr, Kittles RA and Kidd LC: Interaction among variant vascular endothelial growth factor (VEGF) and its receptor in relation to prostate cancer risk. Prostate 70: 341-352, 2010. PMID: 19908237. DOI: 10.1002/ pros. 21067

18 Langsenlehner T, Thurner EM, Renner W, Gerger A, Kapp KS and Langsenlehner $\mathrm{U}$ : Association of genetic variants in VEGF-A with clinical recurrence in prostate cancer patients treated with definitive radiotherapy. Strahlenther Onkol 190: 364-369, 2014. PMID: 24435801. DOI: 10.1007/s00066-0130503-2 
19 Yang B, Cross DF, Ollerenshaw M, Millward BA and Demaine AG: Polymorphisms of the vascular endothelial growth factor and susceptibility to diabetic microvascular complications in patients with type 1 diabetes mellitus. J Diabetes Complications 17: 1-6, 2003. PMID: 12505748. DOI: 10.1016/S1056-8727(02) 00181-2

20 Ungerbäck J, Elander N, Dimberg J and Söderkvist P: Analysis of VEGF polymorphisms, tumor expression of $V E G F$ mRNA and colorectal cancer susceptibility in a Swedish population. Mol Med Rep 2: 435-439, 2009. PMID: 21475847. DOI: 10.3892/mmr_00000118

21 Kapahi R, Manjari M, Uppal MS, Singh NR, Sambyal V and Guleria K: Association of -2549 insertion/deletion polymorphism of vascular endothelial growth factor with breast cancer in North Indian patients. Genet Test Mol Biomarkers 17: 242-248, 2013. PMID: 23390884. DOI: 10.1089/gtmb.2012. 0222

22 Langsenlehner T, Renner W, Gerger A, Hofmann G, Thurner EM, Kapp KS and Langsenlehner U: Impact of $V E G F$ gene polymorphisms and haplotypes on radiation-induced late toxicity in prostate cancer patients. Strahlenther Onkol 187: 784-791, 2011. PMID: 22105769. DOI: 10.1007/s00066-011-1106-4
23 Onen IH, Konac E, Eroglu M, Guneri C, Biri H and Ekmekci A: No association between polymorphism in the vascular endothelial growth factor gene at position -460 and sporadic prostate cancer in the Turkish population. Mol Biol Rep 35: 1722, 2008. PMID: 17216542. DOI: 10.1007/s11033-006-9046-2

24 Lin CC, Wu HC, Tsai FJ, Chen HY and Chen WC: Vascular endothelial growth factor gene $-460 \mathrm{C} / \mathrm{T}$ polymorphism is a biomarker for prostate cancer. Urology 62: 374-377, 2003. PMID: 12893367. DOI: 10.1016/S0090-4295(03)00268-1

25 Al-Habboubi HH, Sater MS, Almawi AW, Al-Khateeb GM and Almawi WY: Contribution of VEGF polymorphisms to variation in $V E G F$ serum levels in a healthy population. Eur Cytokine Netw 22: 154-158, 2011. PMID: 21982816. DOI: 10.1684/ ecn.2011.0289

Received April 10, 2019

Revised April 26, 2019

Accepted May 2, 2019 